$3 \mathrm{~h}$. Workup gave $1.41 \mathrm{~g}(91 \%)$ of recrystallized $\left(\mathrm{CH}_{2} \mathrm{Cl}_{2} / \mathrm{EtOAc}\right)$ 11: $\mathrm{mp} 149-150^{\circ} \mathrm{C} ;[\alpha]_{\mathrm{D}}+51.88^{\circ}(\mathrm{c} 4.8, \mathrm{MeOH}) ;{ }^{13} \mathrm{C}$ NMR $\delta$ $150.00,140.18,129.29,129.07,128.58,126.14,123.03,121.32,117.29$, $112.23,81.83,56.44,47.56,34.20,33.19$; mass spectrum (EI), $m / z$ (relative intensity) 167, $44(100), 148(8),(\mathrm{CI}) 272\left(100, \mathrm{M}^{+}\right)$. Anal. Calcd for $\mathrm{C}_{17} \mathrm{H}_{22} \mathrm{ClNO}_{2}$ : $\mathrm{C}, 66.34 ; \mathrm{H}, 7.15 ; \mathrm{N}, 4.55 ; \mathrm{Cl}, 11.5$. Found: $\mathrm{C}, 66.08 ; \mathrm{H}, 5.29 ; \mathrm{N}, 4.66 ; \mathrm{Cl}, 11.59$.

[S]-(-)-Chloro-3-phenyl-3-(2-methoxyphenoxy)propane (8). Chloro ether 8 was prepared by a procedure similar to the one used for 5: yield, $1.64 \mathrm{~g}(60 \%) ; \mathrm{mp} 59-61^{\circ} \mathrm{C} ;[\alpha]^{23}{ }_{\mathrm{D}}-41.6^{\circ}$ (c $\left.3, \mathrm{CHCl}_{3}\right) ;{ }^{13} \mathrm{C} \mathrm{NMR}$ and mass spectrum were identical with those of 5 .

[S ]-(-)-Nisoxetine Hydrochloride (14). [S]-(-)-Nisoxetine hydrochloride was prepared by a procedure similar to the one used for 11: yield, $1.41 \mathrm{~g}(91 \%) ; \mathrm{mp} 149-151^{\circ} \mathrm{C}$; $[\alpha]^{23}{ }_{\mathrm{D}}-52^{\circ}$ (c 5 , $\mathrm{MeOH}) ;{ }^{13} \mathrm{C}$ NMR and mass spectra were identical with those of 11 .

Acknowledgment. We would like to thank the United States Army Research Office (DAAG 29-82-K-0047) for the financial assistance which made our studies possible.

Registry No. 1, 100306-34-1; 2, 100306-33-0; 3, 114446-47-8; 4, 114446-48-9; 5, 114446-49-0; 6, 114446-50-3; 7, 114446-51-4; 8, 114446-52-5; 9, 82248-59-7; 10, 114247-09-5; 11, 114446-53-6; 12, 82857-39-4; 13, 114247-06-2; 14, 114446-54-7; ${ }^{d} \mathrm{Ipc}_{2} \mathrm{BCl}, 85116-37-6$; ${ }^{2} \mathrm{Ipc}_{2} \mathrm{BCl}, 112246-73-8$; 4'-bromo-4-chlorobutyrophenone, 4559-96-0; 2-chloroacetophenone, 532-27-4; 2-bromoacetophenone, 70-11-1; 2-iodoacetophenone, 4636-16-2; 2'-bromoacetophenone, 2142-69-0; $4^{\prime}$-bromoacetophenone, 99-90-1; 3-chloropropiophenone, 936-59-4; 4-chloropropiophenone, $6285-05-8 ; 2,2^{\prime}, 4^{\prime}$-trichloroacetophenone, 4252-78-2; $[R]$-2-chloro-1-phenylethanol, 56751-12-3; $[R]-2$ bromo-1-phenylethanol, 73908-23-3; $[R]$-2-iodo-1-phenylethanol, 85611-59-2; [S]-1-(2-bromophenyl)ethanol, 114446-55-8; [S]-1(4-bromophenyl)ethanol, 100760-04-1; [S]-2-(4-bromophenyl)tetrahydrofuran, 114446-56-9; [S]-4-chloro-1-phenylbutanol, 65488-06-4; [R]-1-(2,4-dichlorophenyl)-2-chloroethanol, 11444657-0; [S]-1-(4-bromophenyl)-4-chlorobutanol, 114446-58-1; $[R]$ phenyloxirane, 20780-53-4; $o$-cresol, 95-48-7; $\alpha, \alpha, \alpha$-trifluoro- $p$ cresol, 402-45-9; guaiacol, 90-05-1.

\title{
Relative Reactivities of Acetals and Orthoesters in Lewis Acid Catalyzed Reactions with Vinyl Ethers. A Systematic Investigation of the Synthetic Potential of Acetals and Orthoesters in Electrophilic Alkoxyalkylations of Enol Ethers
}

\author{
Uwe von der Brüggen, Roswitha Lammers, and Herbert Mayr* \\ Institut für Chemie der Medizinischen Universität zu Lübeck, Ratzeburger Allee 160, D-2400 Lübeck, \\ Federal Republic of Germany
}

Received January 4, 1988

\begin{abstract}
The relative reactivities of acetals and orthoesters in $\mathrm{BF}_{3} \cdot \mathrm{OEt}_{2}$-catalyzed reactions with methyl vinyl ether $\left(-78^{\circ} \mathrm{C}, \mathrm{CH}_{2} \mathrm{Cl}_{2}\right)$ have been determined by competition experiments. A reactivity increase by 5 orders of magnitude was found in the series: saturated acetals < methyl orthoformate $<$ benzaldehyde acetals $<\alpha, \beta$-unsaturated acetals; formaldehyde acetals as well as orthoacetates and orthobenzoates did not react under these conditions. The $k_{\text {rel }}$ values of the para-substituted benzaldehyde acetals follow a Hammett $\sigma$ correlation $(\rho=-4.6)$. Whereas the $k_{\text {rel }}$ values of the aldehyde acetals are correlated with the corresponding rate constants of acid-catalyzed hydrolyses, ketals and orthoesters deviate from this correlation. It is concluded that the $k_{\text {rel }}$ listing in Scheme II can be used to predict the results of Lewis acid catalyzed additions of acetals and orthoesters toward vinyl ethers: The formation of 1:1 addition products may only be expected, if the relevant functional group of the reactants is listed below the functional group of the potential $1: 1$ products.
\end{abstract}

Müller-Cunradi and Pieroh discovered in 1939 that acetals react with enol ethers in the presence of a Lewis acid to give 3 -alkoxyacetals. ${ }^{1}$ This reaction, which was later suggested to proceed via carbocationic intermediates, ${ }^{2}$ has become an important method in organic synthesis. ${ }^{3}$ Isler's carotine synthesis, for example, employs additions of unsaturated acetals to ethyl vinyl ether and ethyl propenyl ethers as key steps for the construction of the polyene fragment. ${ }^{4}$

Hoaglin and $\mathrm{Hirsch}^{2}$ have already recognized that reaction 1 is not generally appplicable for the synthesis of

(1) Müller-Cunradi, M.; Pieroh, K. U.S. Patent 2 165962; Chem. Abstr. $1939,33,8210$

(2) Hoaglin, R. I.; Hirsch, D. H. J. Am. Chem. Soc. 1949, 71, 3468

(3) Reviews: (a) H. Meerwein In Houben-Weyl, Methoden der Organischen Chemie; Thieme: Stuttgart, 1965, Vol. VI-3, pp 199. (b) Effenberger, F. Angew. Chem. 1969, 81, 374; Angew. Chem., Int. Ed. Engl. 1969, 8, 295. (c) Povarov, L. S. Russ. Chem. Rev. (Engl. Transl.) 1965, 34, 639. (d) Mathieu, J.; Weill-Raynal, J. Formation of C-C Bonds Thieme: Stuttgart, 1979; Vol. III, pp. 196. (e) Makin, S. M. Russ. Chem Rev. (Engl. Transl.) 1969, 38, 237. (f) Makin, S. M. Pure Appl. Chem. $1976,47,173$.

(4) (a) Isler, O.; Lindlar, H.; Montavon, M.; Rüegg, R.; Zeller, P. Helv. Chim. Acta 1956, 39, 249. (b) Isler, O. Angew. Chem. 1956, 68, 547.
1:1 addition products, since the adducts 3 may add to the double bond of 2 in a similar manner as 1, thus leading to the formation of higher adducts. As the yield of the

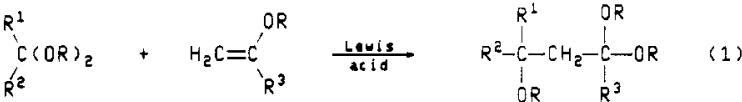

$$
\begin{aligned}
& \stackrel{2}{=} \stackrel{3}{=}
\end{aligned}
$$

$1: 1$ adducts 3 depends on the relative reactivity of the acetals 1 and 3 toward vinyl ethers, several papers were addressed to the relationship between structure and reactivity of acetals. ${ }^{5}$ In an excellent review, Povarov has interpreted the results of acetal and orthoester additions to enol ethers in terms of relative reactivities of reactants and products using the qualitative reactivity sequence: saturated acetals $<$ aromatic acetals $\approx$ ortho esters $<\alpha$,-

(5) (a) Yanovskaya, L. A. Izv. Akad. Nauk SSSR, Ser. Khim. 1965, 1638; Chem. Abstr. 1966, 64, 3342b. (b) Yanovskaya, L. A.; Kucherov, V. F. Izv. Akad. Nauk. SSSR, Ser. Khim. 1965, 1657; Chem. Abstr. 1966 64, 1947c. (c) Fueno, T.; Okuyama, T.; Furukawa, J. J. Polym. Sci., Part A-1 $1969,7,3219$. 
Table I. $\mathrm{BF}_{3} \cdot \mathrm{OEt}_{2}$-Catalyzed Reactions of Acetals and Orthoesters la-t with Methyl Vinyl Ether $2^{\prime}$ in Dichloromethane at $-78^{\circ} \mathrm{C}$

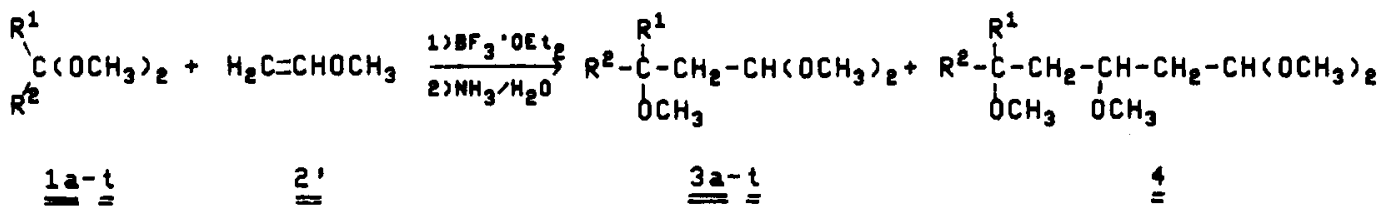

\begin{tabular}{|c|c|c|c|c|c|c|c|c|}
\hline \multirow[b]{2}{*}{$1,3,4$} & \multirow[b]{2}{*}{$\mathrm{R}^{1}$} & \multirow[b]{2}{*}{$\mathrm{R}^{2}$} & \multirow[b]{2}{*}{ Meth $^{a}$} & \multirow[b]{2}{*}{ time $(\mathrm{h})$} & \multicolumn{2}{|r|}{3} & \multicolumn{2}{|r|}{4} \\
\hline & & & & & $\%$ yield & $\mathrm{bp}^{b}$ & $\%$ yield & $\mathrm{bp}^{b}$ \\
\hline $\mathbf{a}$ & $\mathrm{H}$ & $\mathrm{H}$ & A & 46 & & polymerization of $\mathbf{2}^{\prime}$ & & \\
\hline b & $\mathrm{CH}_{3}$ & $\mathrm{H}$ & A & 4 & 60 & $45-47 / 16^{c}$ & 18 & $97-99 / 14^{d}$ \\
\hline c & $\mathrm{CH}_{3} \mathrm{CH}_{2}$ & $\mathrm{H}$ & A & 3 & 49 & $35-40^{e} / 3$ & 34 & $90-100^{e} / 3$ \\
\hline d & $\mathrm{CH}_{3}\left(\mathrm{CH}_{2}\right)_{2}$ & $\mathrm{H}$ & A & 4 & 58 & $30-40^{e} / 1-3$ & 23 & $90-110^{e} / 1$ \\
\hline e & $\left(\mathrm{CH}_{3}\right)_{2} \mathrm{CH}$ & $\mathrm{H}$ & A & 2 & 55 & $25-35^{e} / 2$ & 22 & $60-80^{e} / 0.1$ \\
\hline f & $\mathrm{CH}_{3}$ & $\mathrm{CH}_{3}$ & $\mathrm{~A}$ & 4.5 & 50 & $59-61 / 18$ & 24 & $52-56 / 0.01$ \\
\hline $\mathbf{g}$ & $\mathrm{C}_{6} \mathrm{H}_{5}$ & $\mathrm{H}$ & $\mathrm{A}$ & 5 & 64 & $61-63 / 0.1^{f}$ & 10 & $125-140^{e} / 0.1$ \\
\hline $\mathbf{h}$ & $4-\mathrm{NO}_{2}-\mathrm{C}_{6} \mathrm{H}_{4}$ & $\mathrm{H}$ & A & 72 & & $g$ & & \\
\hline$\overline{\mathbf{i}}$ & $4-\mathrm{Br}-\mathrm{C}_{6} \mathrm{H}_{4}$ & $\mathrm{H}$ & A & 3.5 & 89 & $120-130^{e} / 0.1$ & & \\
\hline $\mathbf{j}$ & $4-\mathrm{Cl}-\mathrm{C}_{6} \mathrm{H}_{4}$ & $\mathrm{H}$ & A & 3.5 & 84 & $70-73^{e} / 0.1$ & & \\
\hline $\mathbf{k}$ & 4-F- $\mathrm{C}_{6} \mathrm{H}_{4}$ & $\mathrm{H}$ & A & 4 & 88 & $70-80^{e} / 0.1$ & & \\
\hline$\overline{1}$ & 4- $\mathrm{CH}_{3}-\mathrm{C}_{6} \mathrm{H}_{4}$ & $\mathrm{H}$ & A & 4 & 86 & $60-70^{e} / 0.1$ & & \\
\hline $\mathbf{m}$ & $4-\mathrm{CH}_{3} \mathrm{O}-\mathrm{C}_{6} \mathrm{H}_{4}$ & $\mathrm{H}$ & A & 4 & 55 & $90-94 / 0.09$ & & \\
\hline $\mathbf{n}$ & $\mathrm{H}_{2} \mathrm{C}=\mathrm{CH}$ & $\mathrm{H}$ & B & 3 & 24 & $58-59 / 18$ & 3 & $60-90^{e} / 0.1$ \\
\hline o & $\mathrm{CH}_{3} \mathrm{CH}=\mathrm{CH}$ & $\mathrm{H}$ & B & 1 & 82 & $81-82 / 26$ & & \\
\hline p & $\mathrm{CH}_{3} \mathrm{CH}=\mathrm{C}\left(\mathrm{CH}_{3}\right)$ & $\mathrm{H}$ & $\mathrm{B}$ & 2 & $67^{h}$ & $45-50^{e} / 1$ & & \\
\hline$q$ & $\mathrm{C}_{6} \mathrm{H}_{5} \mathrm{CH}=\mathrm{CH}$ & $\mathrm{H}$ & $\mathrm{A}^{i}$ & 22 & 49 & $94-114^{e} / 0.06$ & & \\
\hline $\mathbf{r}$ & $\mathrm{H}$ & $\mathrm{CH}_{3} \mathrm{O}$ & $\mathrm{A}$ & 6 & 65 & $63-65 / 20^{j}$ & 8 & $50-51 / 0.006$ \\
\hline $\mathbf{s}$ & $\mathrm{CH}_{3}$ & $\mathrm{CH}_{3} \mathrm{O}$ & A & 72 & & polymerization of $\mathbf{2}^{\prime}$ & & \\
\hline $\mathbf{t}$ & $\mathrm{C}_{6} \mathrm{H}_{5}$ & $\mathrm{CH}_{3} \mathrm{O}$ & A & 24 & & polymerization of $\mathbf{2}^{\prime}$ & & \\
\hline
\end{tabular}

${ }^{a}$ See the Experimental Section. ${ }^{\circ}{ }^{\circ} \mathrm{C} / \mathrm{mbar} .{ }^{c} 46^{\circ} \mathrm{C} / 13 \mathrm{mbar}$ : ref $2 .{ }^{d} 83-85{ }^{\circ} \mathrm{C} / 7 \mathrm{mbar}$ : ref $2 .{ }^{e}$ Bath temperature. ${ }^{f} 112{ }^{\circ} \mathrm{C} / 8 \mathrm{mbar}$ : ref 6b. ${ }^{8}$ No reaction within 3 days at $-26^{\circ} \mathrm{C}$. ${ }^{h}$ Reaction of $1 \mathrm{p}(30.0 \mathrm{mmol})$ and $\mathbf{2}^{\prime}(37.2 \mathrm{mmol})$ yields $3 \mathrm{p}$ and $1.32 \mathrm{~g}$ of an unidentified compound with bp $40-50{ }^{\circ} \mathrm{C}$ (bath) $/ 0.1 \mathrm{mbar} .{ }^{i} 1 \mathrm{q} / 2^{\prime}=1: 1.2 .{ }^{j} \mathrm{Bp} 66-67^{\circ} \mathrm{C} / 16$ mbar: ref $6 \mathrm{c}$.

Table II. ${ }^{13} \mathrm{C}$ NMR Chemical Shifts $(\delta)$ of the $1: 1$ Adducts 3 in $\mathrm{CDCl}_{3}$

\begin{tabular}{|c|c|c|c|c|c|c|c|c|}
\hline no. & $\mathrm{R}^{1}$ & $\mathrm{R}^{2}$ & $\mathrm{C}-1$ & $\mathrm{C}-2$ & $\mathrm{C}-3$ & $1-\mathrm{OMe}$ & $3-\overline{\mathrm{OMe}}$ & other signals \\
\hline $\mathbf{3 b}$ & $\mathrm{Me}$ & $\mathrm{H}$ & 102.18 & 39.86 & 73.35 & $52.73,52.97$ & 55.91 & $19.12(q)$ \\
\hline 3c & Et & $\mathrm{H}$ & 102.46 & 36.96 & 78.48 & $52.90,53.03$ & 56.65 & $9.04(\mathrm{q}), 26.09(\mathrm{t})$ \\
\hline 3d & $n-\operatorname{Pr}$ & $\mathrm{H}$ & 102.40 & 37.46 & 77.38 & $52.81,52.91$ & 56.66 & $14.30(\mathrm{q}), 18.27(\mathrm{t}), 36.05(\mathrm{t})$ \\
\hline $3 \mathbf{e}$ & $i-\operatorname{Pr}$ & $\mathrm{H}$ & 102.78 & 33.74 & 82.31 & $52.50,53.25$ & 57.76 & $17.16(\mathrm{q}), 18.12(\mathrm{q}), 30.24(\mathrm{~d})$ \\
\hline $\mathbf{3 f}$ & $\mathrm{Me}$ & $\mathrm{Me}$ & 102.01 & 42.62 & 73.29 & 52.45 & 49.13 & $25.43(\mathrm{q})$ \\
\hline $3 \mathbf{g}$ & $\mathrm{Ph}$ & $\mathrm{H}$ & 101.97 & 41.27 & 80.31 & $52.88,53.01$ & 56.54 & $126.65(\mathrm{~d}), 127.71$ (d), 128.50 (d), $141.72(\mathrm{~s})$ \\
\hline $\mathbf{3 i}$ & $4-\mathrm{Br}-\mathrm{C}_{6} \mathrm{H}_{4}$ & $\mathbf{H}$ & 101.75 & 41.20 & 79.69 & $52.75,53.09$ & 56.55 & 121.46 (s), 128.34 (d), 131.63 (d), 140.88 (s) \\
\hline $3 \mathbf{j}$ & $4-\mathrm{Cl}-\mathrm{C}_{6} \mathrm{H}_{4}$ & $\mathrm{H}$ & 101.80 & 41.25 & 79.66 & $52.78,53.10$ & 56.55 & $128.02(\mathrm{~d}), 128.71$ (d), $133.37(\mathrm{~s}), 140.36(\mathrm{~s})$ \\
\hline $3 \mathbf{k}$ & $4-\mathrm{F}-\mathrm{C}_{6} \mathrm{H}_{4}$ & $\mathrm{H}$ & 101.95 & 41.38 & 79.71 & $52.81,53.07$ & 56.44 & $\begin{array}{r}115.40\left(\mathrm{dd}, J_{\mathrm{CF}}=21 \mathrm{~Hz}\right), 128.29\left(\mathrm{dd}, J_{\mathrm{CF}}=8.1 \mathrm{~Hz}\right) \\
137.59\left(\mathrm{~d}, J_{\mathrm{CF}}=3.1 \mathrm{~Hz}\right), 176.26\left(\mathrm{~d}, J_{\mathrm{CF}}=152 \mathrm{~Hz}\right)\end{array}$ \\
\hline 31 & 4- $\mathrm{Me}-\mathrm{C}_{6} \mathrm{H}_{4}$ & $\mathrm{H}$ & 102.00 & 41.27 & 80.11 & $52.78,52.92$ & 56.35 & $21.13(\mathrm{q}), 126.62$ (d), $129.18(\mathrm{~d}), 137.31(\mathrm{~s}), 138.69(\mathrm{~s})$ \\
\hline 3m & $4-\mathrm{MeO}-\mathrm{C}_{6} \mathrm{H}_{4}$ & $\mathrm{H}$ & 102.02 & 41.14 & 79.77 & $52.87,53.00$ & 56.25 & $55.23(\mathrm{q}), 113.85(\mathrm{~d}), 127.89(\mathrm{~d}), 133.62(\mathrm{~s}), 159.18(\mathrm{~s})$ \\
\hline $3 \mathbf{n}$ & $\mathrm{CH}_{2}=\mathrm{CH}$ & $\mathrm{H}$ & 101.91 & 38.76 & 79.45 & $52.92,52.96$ & 56.13 & $117.31(\mathrm{t}), 138.26(\mathrm{~d})$ \\
\hline 3o & $\mathrm{MeCH}=\mathrm{CH}$ & $\mathrm{H}$ & 102.01 & 38.92 & 78.93 & $52.89,52.92$ & 55.78 & $17.69(\mathrm{q}), 129.16(\mathrm{~d}), 131$ \\
\hline 3p & $\mathrm{MeCH}=\mathrm{C}(\mathrm{Me})$ & $\mathrm{H}$ & 102.14 & 37.03 & 83.46 & $52.47,52.86$ & 55.44 & $9.99(\mathrm{q}), 12.91(\mathrm{q}), 122.91(\mathrm{~d}), 134.64(\mathrm{~s})$ \\
\hline $3 q$ & $\mathrm{PhCH}=\mathrm{CH}$ & $\mathrm{H}$ & 101.86 & 39.01 & 79.03 & $52.87,53.07$ & 56.24 & $\begin{array}{l}126.51(\mathrm{~d}), 127.80(\mathrm{~d}), 128.60(\mathrm{~d}), 129.54(\mathrm{~d}), 132.55(\mathrm{~d}), \\
\quad 136.45(\mathrm{~s})\end{array}$ \\
\hline $3 \mathbf{r}$ & $\mathbf{H}$ & $\mathrm{MeO}$ & 101.81 & 36.21 & 101.81 & 52.99 & 52.99 & \\
\hline
\end{tabular}

$\beta$-unsaturated acetals. ${ }^{3 c}$ Quantitative data on the relative reactivities of these classes of compounds under Lewis acidic conditions have, to our knowledge, not been reported.

Since such data are needed for the reliable design of syntheses employing reaction 1 , we have carried out competition experiments to determine relative reactivities of acetals and orthoesters toward methyl vinyl ether as a reference nucleophile.

\section{Reaction Products}

When equimolar amounts of the compounds $1 \mathrm{a}-\mathbf{t}$ and methyl vinyl ether $2^{\prime}$ were treated with 0.2 equiv of $\mathrm{BF}_{3} \cdot \mathrm{OEt}_{2}$ in dichloromethane at $-78^{\circ} \mathrm{C}$, the $1: 1$ products 3 , sometimes accompanied by the $2: 1$ products 4 , were obtained in variable yields (Table I). The structures of the adducts 3 and 4 , which are derived from the spectral data given in Tables II and 1S-3S (supplementary material), are in agreement with literature reports, which mostly dealt with the corresponding ethyl acetals. ${ }^{2,6 a}$ Table I shows that aromatic and unsaturated aliphatic acetals, with exception of the $p$-nitro derivative $1 h$, react with methyl vinyl ether $2^{\prime}$ to give good yields of $1: 1$ products. With saturated aliphatic acetals or methyl orthoformate, noticeable amounts of the 2:1 adducts 4 were formed in addition to 3 , and no adducts have been obtained with the formaldehyde acetal $1 \mathrm{a}$ and the orthoesters $1 \mathrm{~s}, \mathrm{t}$. These observations allow us to derive the qualitative reactivity order: formaldehyde acetals, $\mathrm{R}^{\prime} \mathrm{C}(\mathrm{OR})_{3}<$ aliphatic acetals

(6) (a) Nazarov, I. N.; Makin, S. M.; Kruptsov, B. K. Zh. Obshch. Khim. 1959, 29, 3683; Chem. Abstr. 1960, 54, 19462d. (b) Copenhaver, J. W. U.S. Patent 2487525 ; Chem. Abstr. 1950, 44, 3011b. (c) Copenhaver, J. W. U.S. Patent 2527533 ; Chem. Abstr. 1951, 45, $1622 i$. 


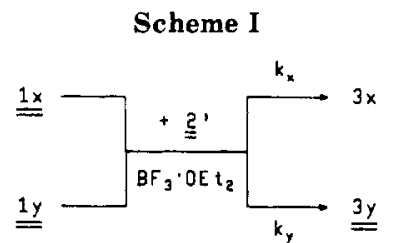

$<\mathrm{HC}(\mathrm{OR})_{3}<$ aromatic acetals $\approx$ unsaturated aliphatic acetals, in accord with previous reports. ${ }^{3 c}$ More precise information comes from competition experiments.

\section{Determination of Relative Reactivities}

Reactivity ratios of different acetals were obtained by adding a small amount of methyl vinyl ether $2^{\prime}$ to a mixture of two acetals or orthoesters $1 x$ and $1 y$ in the presence of 0.2 equiv of $\mathrm{BF}_{3} \cdot \mathrm{OEt}_{2}$ (Scheme I). Since in all experiments a large excess of 1 over $2^{\prime}$ was employed, the formation of the 2:1 products 4 is negligible, and the competition constant $\kappa$ can be derived from the gas chromatographically determined yield of $3 x$ and $3 y$ on the basis of eq 2.7 The competition constants $\kappa$, usually calculated

$$
\kappa=\frac{k_{\mathbf{x}}}{k_{\mathbf{y}}}=\frac{\log [\mathbf{1} \mathbf{x}]_{0}-\log \left([\mathbf{1 x}]_{0}-[\mathbf{3 x}]\right)}{\log [\mathbf{1} \mathbf{y}]_{0}-\log \left([\mathbf{1} \mathbf{y}]_{0}-[\mathbf{3 y}]\right)}
$$

from more than three experiments with different relative acetal concentrations, are shown in the left part of Scheme II. The $\log \kappa$ values are combined to give an overdetermined set of linear equations, which is subjected to a least-squares analysis to yield the $k_{\text {rel }}$ values shown in the right part of Scheme II. Since the reactivity scale from the least reactive acetal $\mathbf{3 b}$ to the most reactive compounds $1 \mathbf{q}, \mathbf{m}, \mathbf{0}$ spans a range of 200000 , the approximately $10 \%$ errors of the $k_{\text {rel }}$ values are irrelevant for the discussion. It should be noted, however, that those competition constants $\kappa$, which refer to reactants with $\Delta G^{\circ}$ (ionization) < 0 , depend on the amount of Lewis acid. ${ }^{8}$ Since the orthoformate $1 \mathbf{r}$ and the acetal 1q are noticeably ionized by $\mathrm{BF}_{3} \cdot \mathrm{OEt}_{2}$ in $\mathrm{CH}_{2} \mathrm{Cl}_{2}$, their $k_{\text {rel }}$ values and those of $1 \mathrm{~m}$ and 10 may vary with the reaction conditions. The other $k_{\text {rei }}$ values shown in Scheme II are expected to be rather insensitive toward changes of the reaction conditions. By analogy with benzhydryl cation additions, one can furthermore expect that the reactivity sequence of Scheme II, which was determined with respect to methyl vinyl ether, will be similar with respect to other $\pi$-nucleophiles. ${ }^{9}$

\section{Discussion}

The qualitative reactivity order, saturated acetals $<$ aromatic acetals $\approx$ ortho esters $<\alpha, \beta$-unsaturated acetals, which was postulated by Povarov, is roughly corroborated by Scheme II though modifications have to be made. One can recognize that variation of the alkyl chain $(1 \mathbf{b}-\mathbf{e})$ has little influence on the reactivity of acetals. The comparison of $1 \mathbf{d}$ with $\mathbf{3 b}$ (reactivity ratio 12.6) gives a measure of the retarding effect of inductively withdrawing groups in the $\beta$-position, which has been recognized by Yanovskaya and Kucherov. ${ }^{5 b}$

When the electron-releasing ability of the para substituents in benzaldehyde acetals is increased, the equilibrium concentration of $\alpha$-alkoxybenzyl cations will grow (Scheme III), but at the same time, the reactivity of the intermediate alkoxybenzyl cations will decrease. In ac-

(7) Huisgen, R. Angew. Chem. 1970, 82, 783; Angew. Chem., Int. Ed. Engl. 1970, 9, 751.

(8) Mayr, H.; Schade, C.; Rubow, M.; Schneider, R. Angew. Chem. 1987, 99, 1059; Angew. Chem. Int. Ed. Engl. 1987, 26, 1029.

(9) Mayr, H.; Schneider, R.; Grabis, U. Angew. Chem. 1986, 98, 1034; Angew. Chem., Int. Ed. Engl. 1986, 25, 1017.

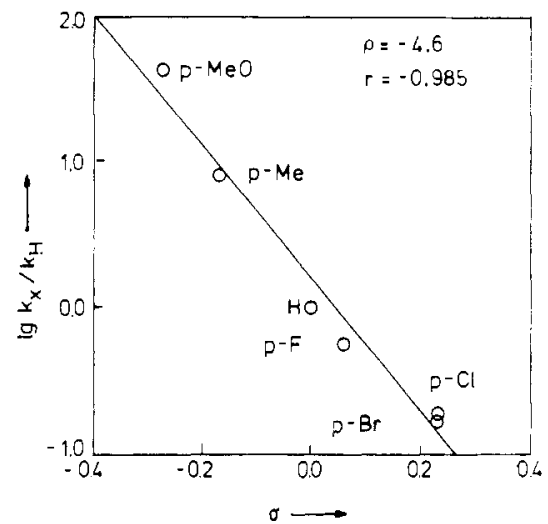

Figure 1. Correlation between the rates of $\mathrm{BF}_{3} \cdot \mathrm{OEt}_{2}$-catalyzed additions of para-substituted benzaldehyde dimethylacetals to methyl vinyl ether with $\sigma$ values.

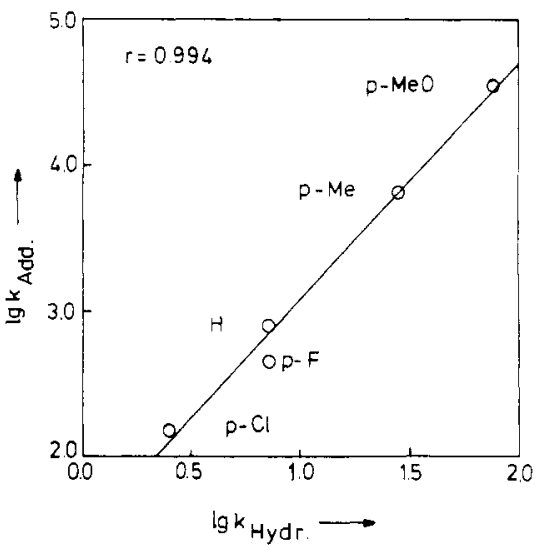

Figure 2. Correlation between the rates of $\mathrm{BF}_{3} \cdot \mathrm{OEt}_{2}$-catalyzed additions of para-substituted benzaldehyde dimethylacetals to methyl vinyl ether with hydrolysis rates of the corresponding diethylacetals in aqueous solution. ${ }^{10 \mathrm{~b}}$

cordance with our findings for benzhydryl systems, the former effect is more important in competition situations with catalytic amounts of Lewis acids, ${ }^{8}$ and Scheme II shows an increase of $k_{\text {rel }}$ when the electron-releasing ability of the para substituents in benzaldehyde acetals is enhanced.

The $\log k_{\text {rel }}$ values of the substituted benzaldehyde acetals give a better correlation with $\sigma$ (Figure 1) than with $\sigma^{+}$values, indicating that the benzylic carbon does not have carbenium like character in the transition state. A similar behavior was reported for acid-catalyzed hydrolyses of benzaldehyde acetals, ${ }^{10}$ and comparison of the $\rho$ values $(-4.6)$ for the $\mathrm{BF}_{3} \cdot \mathrm{OEt}_{2}$-catalyzed additions and -3.3 for acid-catalyzed hydrolyses ${ }^{10 \mathrm{~b}}$ indicates even less positive charge residing at the benzylic carbon in the transition state of acid-catalyzed hydrolyses. The close analogy of these two reaction types is obvious from the almost perfect linear free energy relationship depicted in Figure 2.

NMR studies have shown that the orthoesters $1 \mathbf{r}$ and 1s, like the acetal 1q, are ionized by $\mathrm{BF}_{3} \cdot \mathrm{OEt}_{2}$ in $\mathrm{CD}_{2} \mathrm{Cl}_{2}$, whereas ions were not detectable by ${ }^{1} \mathrm{H}$ NMR spectroscopy when the benzaldehyde acetal $1 \mathrm{~g}$ or aliphatic acetals were treated with $\mathrm{BF}_{3} \cdot \mathrm{OEt}_{2}$ in $\mathrm{CD}_{2} \mathrm{Cl}_{2}$. These experiments show that dialkoxycarbenium ions are better stabilized than alkoxybenzyl cations, and as a consequence of our previous considerations, ${ }^{8}$ one should expect orthoesters to be more reactive than acetals in the presence of catalytic amounts

(10) (a) Fife, T. H.; Jao, L. K. J. Org. Chem. 1965, 30, 1492. (b) Dunlap, R. B.; Ghanim, G. A.; Cordes, E. H. J. Phys. Chem. 1969, 73, 1898. 
Scheme II ${ }^{\circ}$

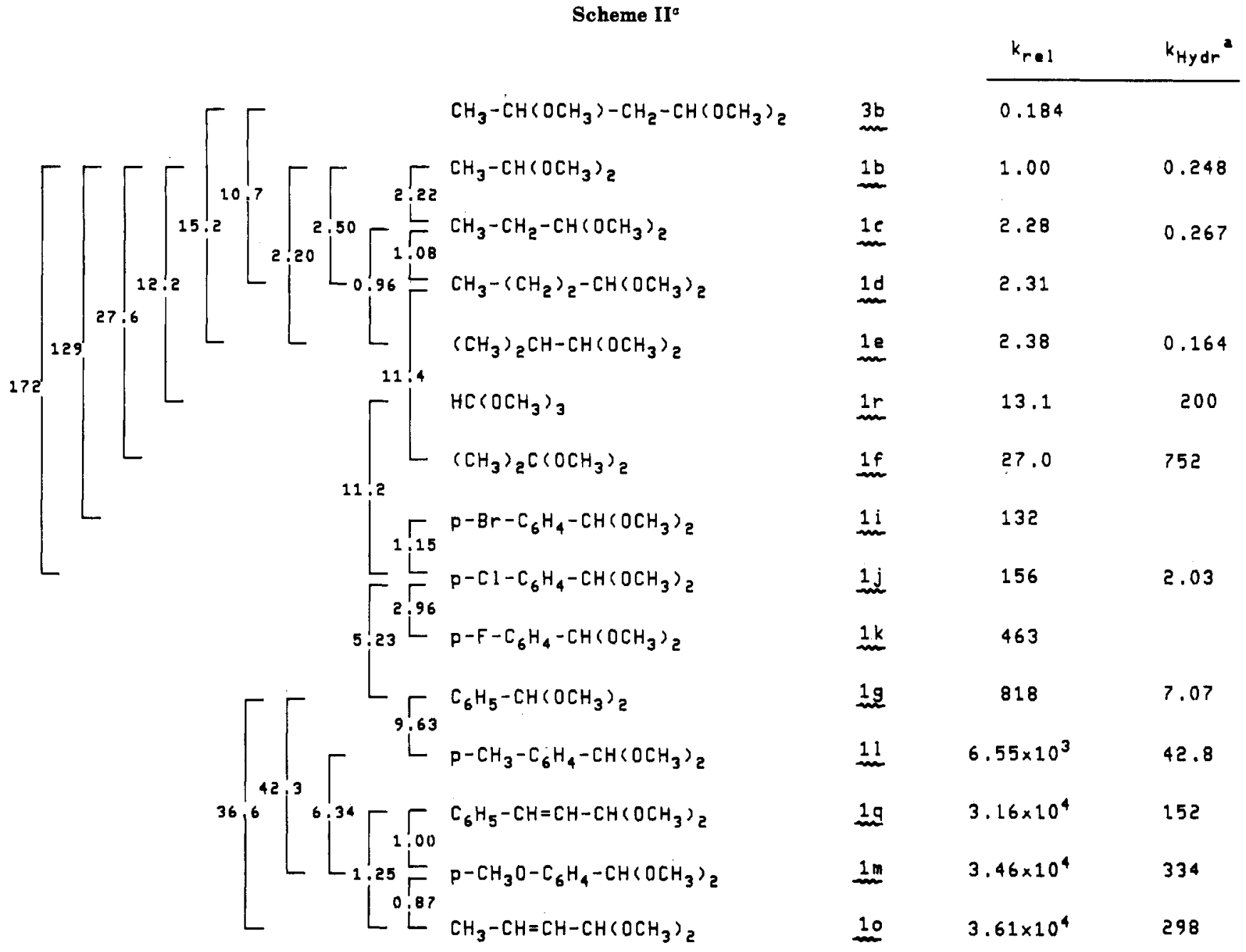

${ }^{a}$ Hydrolysis rate constants of the corresponding ethoxy compounds in dioxane/water $(1: 1)$ at $25^{\circ} \mathrm{C} ; k_{2} / \mathrm{L} \mathrm{mol}^{-1} \mathrm{~s}^{-1}$ from ref $10 \mathrm{a}$ and 13 .

\section{Scheme III}

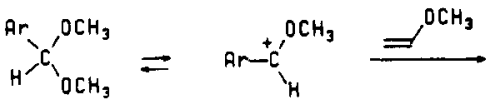

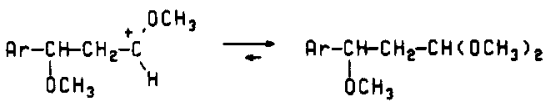

of Lewis acids. Scheme II shows, however, that methyl orthoformate (1r) is only slightly more reactive than saturated acetals, at least 3 orders of magnitude less reactive than expected from the stability of the dialkoxycarbenium ion. Heats of formation of model compounds ${ }^{11}$ have been used to estimate that the addition of methyl orthoformate (1r) to methyl vinyl ether is approximately $4-5 \mathrm{~kJ} / \mathrm{mol}$ less exothermic than the corresponding acetal additions (anomeric effect). Therefore a factor of at most 15 of the reduction of the reactivity of $1 \mathbf{r}$ can be due to the lower thermodynamic driving force. Though one might suspect that the low reactivity of $1 \mathbf{r}$ is caused by the reversibility of the dialkoxycarbenium ion addition to the vinyl ether, a definite explanation for this effect can presently not be given.

The remarkably good correlation of the addition rate constants of benzaldehyde dimethyl acetals with the hydrolysis rates of the corresponding diethyl acetals in water

(11) Pedley, J. B.; Naylor, R. D.; Kirby, S. P. Thermochemical Data of Organic Compounds; Chapman and Hall: London, 1986.

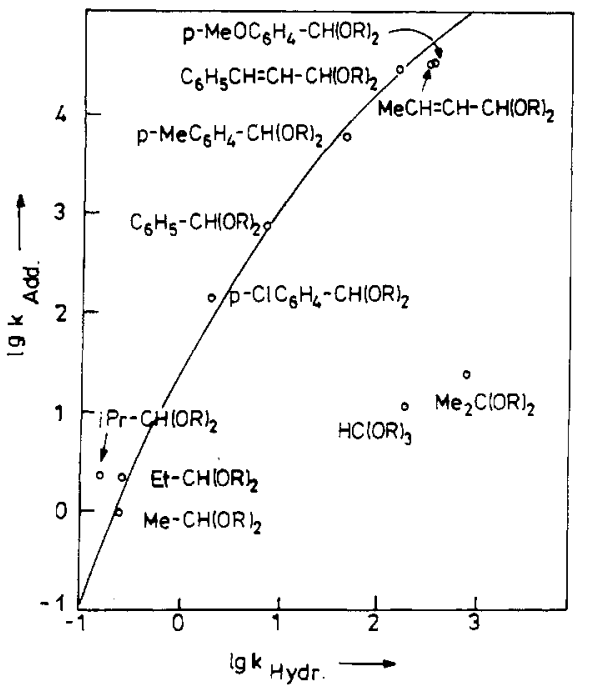

Figure 3. Relationship between the rate constants of $\mathrm{BF}_{3}$.

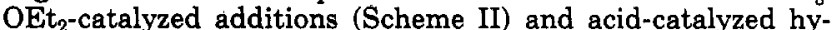
drolyses $^{10 \mathrm{a}, 13 \mathrm{a}}$ of acetals and orthoesters.

(Figure 2) prompted us to plot all $k_{\text {rel }}$ values of Scheme II versus the available hydrolysis rate constants. Though in this case no linear relationship is obtained, a correlation between addition rates of aldehyde acetals and the corresponding hydrolysis rates is obvious from Figure 3. Since orthoesters are hydrolyzed more slowly than expected from the stability of the intermediate dialkoxy- 
carbenium ions, ${ }^{13 \mathrm{~b}}$ the deviation of methyl orthoformate (1r) from the aldehyde acetal correlation line is less than expected from the discussion above. Steric effects probably account for the deviation of the ketal $1 f$ and for the finding that the orthoesters $1 \mathrm{~s}, t$ react considerably more slowly than $1 \mathbf{r}$.

\section{Conclusions}

In previous work we have demonstrated that the results of Lewis acid catalyzed reactions of alkyl halides $\mathbf{5}$ to alkenes 6 can be predicted on the basis of solvolysis rates of model compounds. ${ }^{12}$ If steric effects are negligible and if only small equilibrium concentrations of carbenium ions are involved, the selective formation of $1: 1$ adducts via eq 3 can only be achieved if the reactants 5 solvolyze faster than the products $7.8,12$

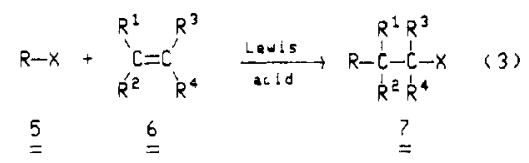

Since Figure 3 shows a correlation between addition and hydrolysis rates of aldehyde acetals, the above rule ${ }^{12}$ can be adapted to predict the outcome of eq 1: Lewis acid catalyzed additions of aldehyde acetals to alkyl vinyl ethers can only give $1: 1$ products if the reactants 1 possess greater hydrolysis rate constants ${ }^{13}$ than the products 3 . Otherwise, polymerization of the vinyl ethers will predominate.

As ketal and orthoester hydrolysis rates are not correlated with the corresponding addition rates (Figure 3), more general predictions can be derived from Scheme II: Lewis acid catalyzed additions of acetals, ketals, or orthoesters to unsaturated aliphatic compounds can only give 1:1 products, if the functional group of the reactants is located below the functional groups of the product in Scheme II.

\section{Applications}

The fivefold reactivity preference of $1 \mathbf{b}$ over $3 \mathbf{b}$ explains that additions of aliphatic acetals to alkyl vinyl ethers may be terminated at the 1:1 product stage, but an excess of acetal is required to obtain high yields of $1: 1$ adducts. $^{2}$ The aromatic and $\alpha, \beta$-unsaturated acetals shown in Scheme II are considerably more reactive than $3 \mathbf{b}$, and $1: 1$ products with alkyl vinyl ethers are also formed in high yield when these acetals and vinyl ethers are employed in equimolar amounts. ${ }^{14}$ For the same reason, a slight excess of orthoformates over alkyl vinyl ethers is sufficient to give high yields of $1: 1$ products. ${ }^{15 a}$

Based on the correlation in Figure 3, the hydrolysis rate constants $\left(25^{\circ} \mathrm{C}\right.$, water $/$ dioxane $=1: 1$ ) of formaldehyde acetal $(\log k=-4.38)^{13 a}$ and $p$-nitrobenzaldehyde acetal $(\log k=-1.76)^{10 a}$ allow us to derive addition rate constants $k_{\text {rel }}$ (Scheme II) of less than 0.1 (slower than $3 \mathbf{b}$ ). The failure to obtain adducts of these acetals with methyl vinyl ether $\left(2^{\prime}\right)$ is thus explained.

(12) (a) Mayr, H. Angew. Chem. 1981, 93, 202; Angew. Chem., Int. Ed. Engl. 1981, 20, 184. (b) Mayr, H.; Striepe, W. J. Org. Chem. 1983, 48, 1159 .

(13) Numerous hydrolysis rate constants are given in ref 10 and in: (a) Kreevoy, M. M.; Taft, R. W., Jr. J. Am. Chem. Soc. 1955, 77, 5590. (b) Cordes, E. H.; Bull, H. G. Chem. Rev. 1974, 74, 581.

(14) (a) Mikhailov, B. M.; Povarov, L. S. Izv Akad. Nauk SSSR, Ser. Khim. 1957, 1239; Chem. Abstr. 1958, 52, 6253f. (b) Nazarov, I. N.; Nazarova, I. I.; Torgov, I. V. Dokl. Akad. Nauk SSSR 1958, 122, 82; Chem. Abstr. 1959, 53, 1123f.

(15) (a) Protopopova, T. V.; Skoldinov, A. P. Zh. Obshch. Khim. 1957, 27, 57; Chem. Abstr. 1957, 51, 11990a. (b) von der Brüggen, U. Dissertation, Med. Univ. Lübeck, 1988.
Since the aliphatic acetals $\mathbf{1} \mathbf{b}-\mathbf{e}$ are less reactive than the ketal if (a model for 8 ), one can rationalize the failure to obtain $1: 1$ adducts 8 from aliphatic acetals and 2propenyl ethers $\left(2^{\prime \prime}\right)$, though 8 can be expected to be somewhat less reactive than $1 \mathrm{f}$ because of the inductively withdrawing $\beta$-substituent (see analogous comparison $3 \mathbf{b} / \mathbf{1 b})$. The isolation of a poor yield of the $1: 1$ adduct

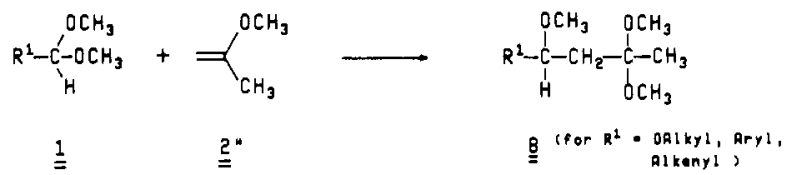

from $1 \mathbf{r}$ and $2^{\prime \prime}$ must also be due to the retarding effect of alkoxy groups in $\beta$-position of the adduct, ${ }^{15 b}$ as $1 \mathbf{r}$ is slightly less reactive than the ketal if (Scheme II). As expected from the large reactivity difference between $\mathbf{~} \mathbf{g}$ and 1f, benzaldehyde dimethyl acetal (1g) was found to give a high yield of $1: 1$ product with $2^{\prime \prime},{ }^{16}$ and unsaturated acetals were reported to behave similarly. ${ }^{17}$

Additions to 1-alkoxybutadienes yield products of type 10 , and in agreement with the numbers in Scheme II, only 4-methoxy- and 3,4-dimethoxybenzaldehyde acetals ${ }^{18}$ and $\alpha, \beta$-unsaturated acetals have been reported to give $1: 1$ products with 1-alkoxybutadienes. ${ }^{3 e, f}$ As expected from

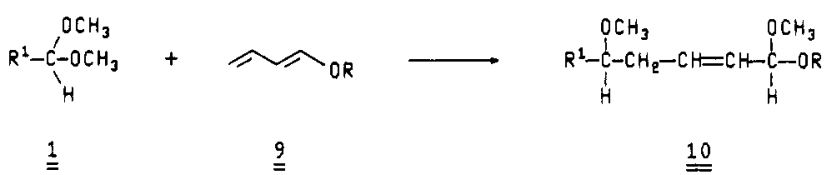

the stabilizing effect of methyl groups, crotonaldehyde acetals give mixtures of $1: 1$ and higher adducts, while $\beta, \beta$-dimethylacrolein acetals yield $1: 1$ adducts selectively. $3 e, f$ The cited examples corroborate our conclusion that Lewis acid catalyzed additions of acetals to unsaturated ethers do not terminate at the $1: 1$ product stage if the reactants are located higher in Scheme II than the products.

How can one avoid polymerisation in such cases? One possibility is to replace the alkoxyalkenes by siloxyalkenes, ${ }^{19}$ since desilylation of the then formed intermediate siloxycarbenium ions is usually faster than attack at another vinyl ether molecule. An alternative method would be to invert the reactivity scale of Scheme II by using stochiometric amounts of strong Lewis acids instead of catalytic amounts. ${ }^{8}$ Though we are not aware of acetal additions carried out under such conditions, the applicability of this principle has recently been demonstrated for related reactions. ${ }^{20}$

\section{Experimental Section}

General Procedures. IR, Shimadzu IR-435; NMR, Varian XL 200; mass spectra, VG 70-250; gas chromatograph, Shimadzu GC-9A with packed column (20\% GE-SE-30), $l=4 \mathrm{~m}, \phi=3 \mathrm{~mm}$; preparative MPLC separations were carried out on $30 \times 2.5 \mathrm{~cm}$ glass columns packed with Lichroprep $\mathrm{Si} 60(15-25 \mu \mathrm{m}) \mathrm{SiO}_{2}$ or $\mathrm{RP}_{18}$ with the pump Gilson Model 302 and the differential refractometer Latek RI 201. Dichloromethane was distilled over $\mathrm{P}_{4} \mathrm{O}_{10}$ and successively refluxed over $\mathrm{CaH}_{2}$, distilled, and stored

(16) Mikhailov, B. M.; Povarov, L. S. Izv. Akad. Nauk SSSR, Ser. Khim. 1959, 1948; Chem. Abstr. 1960, 54, 10952 c.

(17) Mikhailov, B. M.; Povarov, L. S. Zh. Obshch. Khim. 1959, 29, 2079; Chem. Abstr. 1960, 54, $10851 f$.

(18) Makin, S. M.; Shavrygina, O. A.; Dobretsova, E. K.; Ermakova G. A.; Dymshakova, G. M. Zh. Org. Khim. 1982, 18, 749; Chem. Abstr. $1982,97,91857 b$.

(19) (a) Reetz, M. T. Angew. Chem. 1982, 94, 97; Angew. Chem., Int. Ed. Engl. 1982, 21, 96. (b) Mukaiyama, T. Org. React. 1982, 28, 203. (c) Mukaiyama, T.; Murakami, M. Synthesis 1987, 1043.

(20) (a) Mayr, H.; von der Brüggen, U. Chem. Ber. 1988, 121, 339. (b) von der Brüggen, U.; Mayr, H. Chem. Ber. 1988, 121, 191. 
in a nitrogen atmosphere. $\mathrm{BF}_{3} \cdot \mathrm{OEt}_{2}$ was distilled over $\mathrm{CaH}_{2}{ }^{21}$ and stored in a nitrogen atmosphere.

Acetals and Orthoesters $1 a-t$. Compounds $1 \mathbf{a}, \mathbf{b}, \mathbf{f}, \mathbf{g}, \mathbf{n}, \mathbf{r}, \mathbf{s}, \mathbf{t}$ are commercially available. The acetals $1 \mathrm{c}-\mathrm{e}$ were prepared from the corresponding aldehydes and methanol in presence of $\mathrm{CaCl}_{2},{ }^{22}$ and compounds $1 \mathrm{~g}-\mathrm{m}$ and $10-\mathbf{q}$ were obtained by treating the corresponding aldehydes with methyl orthoformate in the presence of catalytic amounts of $\mathrm{NH}_{4} \mathrm{NO}_{3} .{ }^{23}$

$\mathrm{BF}_{3} \cdot \mathrm{OEt}_{2}$-Catalyzed Reactions of $1 \mathrm{a}-\mathrm{t}$ with Methyl Vinyl Ether 2'. Method A. $\mathrm{BF}_{3} \cdot \mathrm{OEt}_{2}(0.75 \mathrm{~mL}, 6.0 \mathrm{mmol})$ was added to a solution of $1(30.0 \mathrm{mmol})$ in $30 \mathrm{~mL}$ of $\mathrm{CH}_{2} \mathrm{Cl}_{2}$ at $-78^{\circ} \mathrm{C}$. A solution of $2^{\prime}(1.74 \mathrm{~g}, 30.0 \mathrm{mmol})$ in $20 \mathrm{~mL}$ of $\mathrm{CH}_{2} \mathrm{Cl}_{2}$ was added within $30 \mathrm{~min}$. After the mixture was stirred at $-78^{\circ} \mathrm{C}$ for some time (see Table I), $20 \mathrm{~mL}$ of concentrated aqueous ammonia were added, and the aqueous layer was extracted with two $20-\mathrm{mL}$ portions of ether. The combined organic layers were dried with $\mathrm{CaCl}_{2}$ and distilled.

Method B. A solution of $1(30.0 \mathrm{mmol})$ and $2^{\prime}(1.74 \mathrm{~g}, 30.0$ $\mathrm{mmol}$ ) in $40 \mathrm{~mL}$ of $\mathrm{CH}_{2} \mathrm{Cl}_{2}$ was added dropwise within $1 \mathrm{~h}$ to a precooled $\left(-78^{\circ} \mathrm{C}\right)$ solution of $\mathrm{BF}_{2} \cdot \mathrm{OEt}_{2}$ in $10 \mathrm{~mL}$ of $\mathrm{CH}_{2} \mathrm{Cl}_{2}$. The mixture was worked up as in method $\mathrm{A}$. Results are given in Table I and physical and spectral data of the adducts 3 and 4 in Table II and $1 S-3 S$.

Competition Experiments. Two of the compounds $1 \mathrm{~b}-\mathrm{r}$ or $3 \mathbf{b}$ were placed into a $100-\mathrm{mL}$ flask in a nitrogen atmosphere. In order to obtain mixtures suited for GC analysis, the more reactive compound $(\approx 0.4 \mathrm{mmol})$ was combined with an excess of the less reactive compound so that the ratio of adducts was between 1 and 10. After the addition of $0.05 \mathrm{mmol}$ of the standard $(5 \mathrm{~mL}$

(21) Zweifel, G.; Brown, H. C. Org. React. 1963, 13, 28

(22) Effenberger, F.; Prossel, G.; Fischer, P. Chem. Ber. 1971, 104, 2002.

(23) Organikum, Organisch-Chemisches Grundpraktikum, 15th Ed. VEB Deutscher Verlag der Wissenschaften, Berlin, 1977; $\mathrm{p} 488$. of a $0.01 \mathrm{M}$ solution of ethylbenzene or hexamethylbenzene in $\left.\mathrm{CH}_{2} \mathrm{Cl}_{2}\right), 45 \mathrm{~mL}$ of $\mathrm{CH}_{2} \mathrm{Cl}_{2}$ was added, and the mixture was cooled at $-78^{\circ} \mathrm{C}$. With a gas-tight Hamilton syringe, $\sim 4.5 \mathrm{~mL}(0.20$ $\mathrm{mmol}$ ) of $\mathbf{2}^{\prime}$ was added and the reaction was initiated by adding $\mathrm{BF}_{3} \cdot \mathrm{OEt}_{2}$ ( 0.2 equiv based on the total amount of acetals). After $1 \mathrm{~h}$ the reaction was terminated by adding concentrated aqueous ammonia. The organic layer was dried with $\mathrm{CaCl}_{2}$, and the bulk of solvent was carefully evaporated in vacuo to give a residue, which was analyzed by GC (20\% GE-SE-30; carrier $\mathrm{N}_{2}, 50$ $\mathrm{mL} / \mathrm{min}$ ). Details of the GC separations are given in Table $4 \mathrm{~S}$, and the competition experiments (quantities of reactants and products) are listed in Table $5 \mathrm{~S}$.

Acknowledgment. We thank the Deutsche Forschungsgesellschaft and the Fonds der Chemischen Industrie for financial support, Dynamit Nobel and Degussa for gifts of chemicals, and Dr. E. Bäuml for discussions.

Registry No. 1a, 109-87-5; 1b, 534-15-6; 1c, 4744-10-9; 1d, 4461-87-4; 1e, 41632-89-7; 1f, 77-76-9; 1g, 1125-88-8; 1h, 881-67-4; 1i, 24856-58-4; 1j, 3395-81-1; 1k, 32691-93-3; 11, 3395-83-3; 1m, 2186-92-7; 1n, 6044-68-4; 1o, 21962-24-3; 1p, 77731-51-2; 1q, 4364-06-1; 1r, 149-73-5; 1s, 1445-45-0; 1t, 707-07-3; 2', 107-25-5; $\left(\mathbf{2}^{\prime}\right)_{x}, 9003-09-2 ; 3 \mathbf{b}, 10138-89-3$; 3c, 32377-24-5; 3d, 6281-05-6; 3e, 114533-81-2; 3f, 73452-12-7; 3g, 26278-70-6; 3i, 114533-82-3; 3j, 114533-83-4; 3k, 114533-84-5; 31, 114533-85-6; 3m, 114533-86-7; 3n, 114533-87-8; 3o, 114533-88-9; 3p, 114533-89-0; 3q, 114533-90-3; 3r, 102-52-3; 4b, 25724-11-2; 4c, 114533-91-4; 4d, 86218-77-1; 4e 114533-92-5; 4f, 114533-93-6; 4g, 114533-94-7; 4h, 114533-95-8; $4 \mathbf{r}, 55546-58-2$.

Supplementary Material Available: Tables with ${ }^{1} \mathrm{H}$ NMR, IR, mass spectroscopic, and analytical data of compounds 3 and $4,{ }^{13} \mathrm{C}$ NMR data of compounds 4, and experimental details of the competition experiments (14 pages). Ordering information is given on any current masthead page.

\title{
trans-Bis(5-methoxy-1-3- $\eta^{3}$-cyclohexenyl)palladium Complexes by Palladium(II)-Promoted Addition of Methanol to 1,4-Cyclohexadienes. Synthesis of Methyl trans-5-Methoxy-2-cyclohexene-1-carboxylates by Subsequent Methoxycarbonylation ${ }^{1}$
}

\author{
Björn C. Söderberg, Björn Åkermark,* and Stan S. Hall*,2 \\ Department of Organic Chemistry, Royal Institute of Technology, S-100 44 Stockholm, Sweden, and \\ Department of Chemistry, Rutgers University, Newark, New Jersey 07102
}

Received December 11, 1987

\begin{abstract}
1,4-Cyclohexadienes in the presence of bis(acetonitrile)palladium dichloride in methanol are stereoselectively converted to trans-bis(5-methoxy-1-3- $\eta^{3}$-cyclohexenyl)palladium chloride complexes. A series of substituted 1,4-cyclohexadienes was studied to determine the effects of substituents. Subsequent methoxycarbonylation regioselectively and stereoselectively afforded the corresponding methyl trans-5-methoxy-2-cyclohexene-1carboxylates. The two-reaction sequence can be coupled in a tandem reaction procedure.
\end{abstract}

Applications of ( $\eta^{3}$-allyl)palladium complexes in organic synthesis engenders keen interest today. ${ }^{3}$ Standard pro-

(1) (a) 1,4-Diene-Derived ( $\eta^{3}$-Allyl)palladium Complexes. 3. Part 1: Hall, S. S.; Âkermark, B. Organometallics 1984, 3, 1745-1748. (b) Part 2: Åkermark, B.; Söderberg, B. C.; Hall, S. S. Ibid. 1987, 6, 2608-2610. (c) Initially disclosed at the 194th National Meeting of the Americal Chemical Society, New Orleans, LA, Aug 1987, paper ORGN 213, and at the XIIth International IUPAC Conference on Organometallic Chemistry, Vienna, Austria, Sept 1985. (d) Taken from the Ph.D. (Teknisk Doktor) Dissertation of B.C.S., Royal Institute of Technology, Dec 1987.

(2) Visiting professor and Rutgers University Faculty Academic Study Participant at the Royal Institute of Technology, July 1982-Aug 1983, July-Aug 1984, July-Aug 1985. cedures to form $\left(\eta^{3}\right.$-allyl)palladium complexes include palladium(II)-initiated addition of nucleophiles across 1,3-diene systems. ${ }^{4}$ Larock recently demonstrated that

(3) (a) Trost, B. M. Tetrahedron 1977, 33, 2615-2649. (b) Chiusoli G. P.; Cassar, L. In Organic Synthesis Via Metal Carbonyls; Wender, I. Pino, P., Eds.; Wiley: New York, 1977; Part II, p 297. (c) Trost, B. M Acc. Chem. Res. 1980, 13, 385-393. (d) Tsuji, J. Organic Synthesis with Palladium Compounds; Springer Verlag: New York, 1980. (e) Trost, B. M.; Verhoeven, T. R. In Comprehensive Organometallic Chemistry; Wilkinson, G. Ed.; Pergamon: Oxford, 1982; Vol. 8, p 799.

(4) (a) Robinson, S. D. Shaw, B. L. J. Chem Soc $1964,5002-5008$ (b) Heck, R. F. J. Am. Chem. Soc. 1968, 90, 5542-5546. (c) Staken, F. G.; Heck, R. F. J. Org. Chem. 1980, 45, 3584-3593. (d) Bäckvall, J.-E. Acc. Chem. Res. 1983, 16, 335-342. 